See discussions, stats, and author profiles for this publication at: https://www.researchgate.net/publication/306013358

\title{
Basics of Mobile Marketing Strategy
}

Chapter · January 2016

DOI: 10.4018/978-1-4666-9776-8.ch008

CITATION

READS

1

1,951

2 authors, including:

Wilson Ozuem

4. Queen's University (Canada) and the University of Cumbria (UK)

79 PUBLICATIONS 271 CITATIONS

SEE PROFILE

Some of the authors of this publication are also working on these related projects:

Call for submission to Special IJEBL Issue on Digital Marketing for luxury and fashion brands View project

HIGH-END ENCROACHMENT: THE AFFORDABILITY EFFECT ON DISRUPTIVE INNOVATION View project 


\section{Competitive Social Media Marketing Strategies}

Wilson Ozuem

University of Gloucestershire, UK

Gordon Bowen

Regent's University London, UK

A volume in the Advances in Marketing, Customer

Relationship Management, and E-Services

(AMCRMES) Book Series 
Published in the United States of America by

Business Science Reference (an imprint of IGI Global)

701 E. Chocolate Avenue

Hershey PA, USA 17033

Tel: 717-533-8845

Fax: 717-533-8661

E-mail: cust@igi-global.com

Web site: http://www.igi-global.com

Copyright ( $) 2016$ by IGI Global. All rights reserved. No part of this publication may be reproduced, stored or distributed in any form or by any means, electronic or mechanical, including photocopying, without written permission from the publisher. Product or company names used in this set are for identification purposes only. Inclusion of the names of the products or companies does not indicate a claim of ownership by IGI Global of the trademark or registered trademark.

Library of Congress Cataloging-in-Publication Data

Names: Bowen, Gordon, 1950- editor. I Ozuem, Wilson, 1974- editor.

Title: Competitive social media marketing strategies / Gordon Bowen and

Wilson Ozuem, editors.

Description: Hershey, PA : Business Science Reference, [2016] I Includes

bibliographical references and index.

Identifiers: LCCN 2015041982| ISBN 9781466697768 (hardcover) I ISBN

9781466697775 (ebook)

Subjects: LCSH: Internet marketing--Social aspects. I Online social networks.

I Social media. I Marketing--Social aspects.

Classification: LCC HF5415.1265 C6544 2016 I DDC 658.8/72--dc23 LC record available at http://lccn.loc.

gov/2015041982

This book is published in the IGI Global book series Advances in Marketing, Customer Relationship Management, and EServices (AMCRMES) (ISSN: 2327-5502; eISSN: 2327-5529)

British Cataloguing in Publication Data

A Cataloguing in Publication record for this book is available from the British Library.

All work contributed to this book is new, previously-unpublished material. The views expressed in this book are those of the authors, but not necessarily of the publisher.

For electronic access to this publication, please contact: eresources@igi-global.com. 


\title{
Chapter 8 \\ Basics of Mobile \\ Marketing Strategy
}

\author{
Wilson Ozuem \\ University of Gloucestershire, UK \\ Bibi Nafiisah Mulloo \\ London Metropolitan University, UK
}

\begin{abstract}
Recent years have witnessed a rapid growth in internet-enabled devices, including smartphones which have facilitated the performance of many tasks online. One of the major activities taking place on such online platforms is shopping. Indeed, smartphones are redefining the landscape of consumption from visiting conventional physical shops to consuming products and services in a digital arena. Despite a proliferation of both theoretical and empirical studies on smartphones marketplace, there is still a paucity of studies on how mobile phone devices enhance and facilitate consumption from physical marketplace to online marketspace. This chapter aims to contribute to extant studies on how smartphones impact on the consumption process.
\end{abstract}

\section{INTRODUCTION}

The mobile revolution in the last decade has re-created a new era of an always-connected society which has reshaped the retail industry, including the clothing sector, in a major way (Euromonitor, 2013). Mobile devices becoming more powerful with their own operating systems, has given rise to a new marketing strategy enabling companies to connect to their consumers on the go and on a 24-hour basis (Emarketer, 2013). This new phenomenon has impacted on the purchasing behaviour of consumers in the clothing sector as well, who are increasingly adopting this new shopping medium. This emerging trend has resulted in all major clothing retailers working to gain online presence with a view to achieving a stronger customer relationship and sustaining a strong presence in the clothing industry which is becoming highly competitive (Keynote, 2009). With the rise of more sophisticated mobile devices, namely smartphones, this new convergence has resulted in powerful consumers who now have their stores in their hands (Abrams, 2013).

DOI: $10.4018 / 978-1-4666-9776-8 . c h 008$

Copyright $@$ (2016, IGI Global. Copying or distributing in print or electronic forms without written permission of IGI Global is prohibited. 
The purchasing habits of consumers have undergone a drastic shift from traditional physical high street shopping to home shopping (Keynote, 2013; Ozuem, Howell \& Lancaster 2008). The role of salesmen and shopping displays has now been eclipsed with modern ways of shopping using technology. Research by Euromonitor (2013) identified consumers who increasingly favour seeking shopping information on their smartphones rather than consulting a salesperson or relying on adverts. The use of smartphones is thus not limited to buying online but rather it is that device which accompanies the consumers in their shopping experience such as browsing for product information, product reviews, price comparisons, consulting friends and families prior to shopping, or simply buying online. "This unique ability has transformed the social and spatial aspects of shopping for many consumers" (Brown et al., 2003). In fact, the ongoing connectivity and exposure to shopping information are resulting in an 'always shopping' state of mind (Babbitts, 2013). If the art of mobile marketing is effectively and efficiently mastered by retailers, this can lead to strong positioning in their respective market. Although this new marketing trend has had a strong influence in different retail sectors, a survey carried out by Emarketer (2013) showed that consumers in the apparel sector still favour physical purchase or buying via the PC rather than smartphones when buying online. The main hindrance to buying via smartphones is usually a non-user friendly mobile site (Emarketer, 2013). The answer to successful retailing via smartphones relies on a strong technique and the application of mobile commerce (Branki et al., 2008). Despite consumers showing a preference to shop or buy clothing in physical shops, being "creatures of convenience" there are billions reaching first for their phones when they think about shopping (Boyle, 2013). Much is assumed about the supposed effects of smartphones on the luxury fashion sector, but much research in the field suffers from epistemological and ontological incompatibility and can be interpreted in various conflicting ways. This chapter focuses on the impact of smartphones on consumer buying behaviour, particularly on the UK luxury fashion sector.

A rapid growth in internet-enabled devices including smartphones has taken place in recent years, allowing many tasks to be performed online (Euromonitor, 2013). One of the major activities taking place on these online platforms is shopping. Indeed, shopping has changed the landscape of consumption from visiting conventional physical shops to consuming products and services in a digital arena (San-Martin and Lopez-Catalan, 2013). Boyle (2013) posited that the number of consumers using smartphones to shop is expanding and consumers are now more willing to reach for their smartphones first when the idea of shopping strikes. This global phenomenon is affecting different parts of the world. A survey conducted in June 2013 by Emarketer (2013), shows that China is the leading country in terms of internet users purchasing via mobile devices followed by India and the United Kingdom. The UK was amongst the first nations to embrace digital shopping and buying and to date it continues to consume goods and services digitally at a pace greater than most other western European countries (Abrams, 2013). The UK's communications regulator Ofcom recently claimed that the UK leads among all other European countries with the highest number of smartphone users (Euromonitor, 2013). UK retail ecommerce sales are estimated to have risen from $£ 38.48$ billion in 2012 to $£ 45.40$ billion in 2013 with a further increase of 15\% forecast for 2014 (Emarketer, 2013). This new trend in purchasing via mobile devices has initiated a new type of e-commerce commonly referred to as retail mobile commerce (m-commerce) which is defined by eMarketer (2013) as "products and services purchased using a browser or app via any mobile device, regardless of where fulfilment occurs." As the growth of m-commerce is overwhelming in the UK, shopping via mobile devices is becoming the norm for internet shoppers with smartphones: mobile commerce sales are forecast to more than double by 2017 (McCarthy, 2013). With such a proliferation of technologically advanced smartphones and the widespread availability of the internet in the UK, digital 
shoppers increasingly expect an enhanced mobile shopping experience (Boyle, 2013). This has highlighted the importance of mobile commerce for retailers as consumer buying behaviour has undergone a significant transformation (Persaud \& Azhar, 2012). To survive in this new era, several retailers in the $\mathrm{UK}$ are at the forefront of m-commerce with major clothing retailers such as Net-a-Porter and Asos as two examples of fashion organisations with the most innovative websites and apps which help them to maintain customer relationships (Abrams, 2013). However, m-commerce is still considered to be in its infancy with most internet users favouring the PC to buy online (Emarketer, 2013). This new shopping trend with its ongoing challenge makes it interesting to investigate the effects of smartphone usage on users' purchase intentions.

\section{THEORETICAL FRAMEWORK AND CONTEXT}

Feature phones are now being gradually eclipsed by the proliferation of smartphones which are more sophisticated in terms of their functionality (Nokia, 2013; Li et al., 2012; Kumar and Mukherjee, 2013, Holmes et al., 2014). Technological advancement in mobile devices fuelled by the widespread availability of high-speed internet access has enhanced various features and the usage of mobile phones (Persaud \& Azhar, 2012; Flint \& Spaid, 2014; Schuster et al., 2013). In fact, the rapid growth of internet-enabled mobile devices has redefined the primary purpose of phones, from devices primarily designed for callmaking to a product capable of performing different functions such as web browsing, emailing, shopping and other tasks (Hu et al., 2006; Ting et al., 2011; Swilley et al., 2012; Ozuem, O'Keeffe, \& Lancaster 2015). A smartphone is a programmable phone which provides its user with advanced capabilities and features to enhance his/her daily work and personal life (Yang \& Kim, 2012).

The rolling out of $3 \mathrm{G}$ and the EE 2012 launch of $4 \mathrm{G}$ in the UK has boosted mobile internet speed which enables users to have a more enriching browsing experience (BBC, 2012; Kumar \& Zhan, 2003; Yang, 2012). Although UK mobile operators have restrained their generous unlimited mobile data offerings, mobile internet subscriptions and smartphone use are still witnessing constant growth (The Guardian, 2012). This can be attributed to the fact that consumers are now less reliant on mobile networks in the UK as the number of Wi-Fi spots available is increasing in cafes, transport hubs and other public places (Yang, 2012). The smartphone is now seen more and more as the must-have device that permits users to perform a multitude of tasks with no time or location constraints (Wong, 2012). The growing dependency on smartphones has revolutionised the lifestyle and behaviour of consumers in different sectors creating a digital landscape where consumers are engulfed in their own worlds anywhere and anytime (Elkin, 2012). For many individuals the smartphone is not only a personal device but it is "an extension of their personality and individuality" (Persaud \& Azhar, p.418). A mobile device, for example in this study the smartphone, can be accessed anytime, anywhere, allowing access to the mobile web in more diverse contexts (Kim et al., 2002). Thanks to its capacity of seamlessly integrating Bluetooth, GPS and other technologies, the smartphone is considered a useful tool that can provide a superior consumer experience (Swilley \& Hofacker, 2006). Moreover, with smartphones at more affordable prices, the rate of adoption is ever-increasing with no signs of abating, thus emphasising the central importance smartphones are gradually and surely taking in consumers' decision making process (Pasqua \& Elkin, 2013). The rapid development and deployment of internet-enabled mobile devices has led to the emergence of highly sophisticated applications commonly referred to as mobile commerce (m-commerce) (Wang et al., 2007; Wheeler, 2013; San-Martin et al., 2012; Wong, 2012). 
Mobile commerce is commonly referred to as the ability to undertake commercial transactions through a wireless internet-enabled device (Swilley et al., 2012). Most definitions of m-commerce focus on an extension of e-commerce (Frolick \& Chen, 2004; Siau et al., 2001; Dholakia \& Dholakia, 2004). It is even considered an unprecedented business opportunity for e-commerce (Wang et al., 2007; Yeh and $\mathrm{Li}, 2009$; Wheeler, 2013). It is the medium through which retailers can develop their marketing strategies, as it is the channel that has the potential to initiate purchase intentions in consumers. However, $\mathrm{m}$-commerce is not regarded as a replacement to e-commerce but rather as a supplement (Clarke, 2008). Mobile commerce in the UK has been effectively adopted due to the widespread availability of high-speed internet access via mobile devices which render mobile shopping readily accessible to consumers (Mintel, 2013). Research conducted by Ipsos and RetailMeNot.com in August 2013 suggest that UK remains the highest user of m-commerce among developed nations (eMarketer, 2013). In this respect, the importance of m-commerce cannot be ignored when conducting this research. Therefore, the ubiquity of smartphones and wireless technology are both important elements that indirectly affect consumers' purchase intentions.

Smartphones being the medium that has a growing influence on consumers purchase intention and buying habits, marketers have an increasing challenge to stay updated and on track about how to maximise consumer retention by adopting appropriate mobile marketing strategies (Elkin, 2013). Ranging from online advertisement, QR codes, Apps development and Geo-fencing, marketers have the enormous responsibility of deterring consumers from being influenced by showrooming (BBC, 2013). Showrooming is defined as the activity of going online while in-store to determine which competitors are offering a better deal for the product a consumer is currently looking to buy (Abrams, 2013). From search engines to deal sites, it has become crucial for companies to capitalise fully on the digital landscape to enhance their online presence (Ahrens et al., 2013). This has become a necessity for the clothing sector as even though mobile shopping may not culminate in purchasing via mobiles, consumers in this sector still rely heavily on their smartphones to browse for product information, deals and purchase-related queries (Cho \& Fiorito, 2009). This on-going thirst for information has emphasised to retailers the importance of enhancing their mobile commerce strategies to remain competitive in what is a highly digitalised shopping era (Skeldon, 2012).

The main activities undertaken by consumers on their smartphones include contacting friends about shopping matters, carrying out price checks, looking at product availability, finding out product information while in-store, accessing social media, acquiring / redeeming coupons, carrying out location-based search, consulting maps, using apps, buying products using devices and even buying products using devices while in-store. These suggest the powerful influence of effective mobile commerce on consumers' online shopping experience. For the purposes of this chapter, smartphones include all mobile phone devices which can access the internet via mobile networks or Wi-Fi spots. Mobile shopping and online consumer behaviour will be discussed further in this chapter in order to understand how smartphones can influence purchase intention.

\section{Attitudes towards Technology}

A number of studies have focused on research on key factors that influence the acceptance of new technologies (Ajzen, 1985; Davis et al., 1989; Lu et al., 2003). To understand how smartphones can affect consumers' purchase intentions and behaviour, it is indispensable to understand the user perception of the use of the technology (Kumar and Mukherjee, 2013). The Theory of Reasoned Action (TRA) suggests 
that the intention to undertake a behaviour is influenced by a person's attitudes towards that behaviour and a subjective norm (Fishbein \& Ajzen, 1975). Attitude in this context is further defined by Spaid and Flint (2014) as an individual positive or negative feeling towards a specific behaviour. Fishbein and Ajzen (1975, p.302) refer to a subjective norm as "perception that most people who are important to him think that he should not perform the behaviour in question." The theory of reasoned action (TRA) implies that any factors that influence a person's behaviour do so through a change of attitudes, subjective norms or a combination of the two (Spaid \& Flint, 2014). The theory of reasoned action (TRA) is considered fairly robust in predicting and explaining cognitively driven attitude (Spaid and Flint, 2014). To address some of the limitations of the TRA, Ajzen (1991) attributes the element of control as another determinant to behavioural intention and actual behaviour. The theory of planned behaviour (TPB) was thus created by Ajzen (1991) to study a perceived lack of control when it comes to certain behaviours. Both theories assist Spaid and Flint (2014) in understanding shoppers' attitudes towards mobile devices.

The TRA was further modified by Davis et al. (1989) where the element of subjective norm was dropped in the process. The Technology Acceptance Model (TAM) was thus devised where two main variables were added to the fundamental process of attitude, intention and behaviour. The TAM attempts to understand how users accept and use the technology (Lu et al., 2003). The two main variables in the original TAM are "perceived usefulness" and "perceived ease of use" (Davis, 1989, cited in Kumar and Mukherjee, 2013, p. 25). These two determinants are considered useful indicators of the attitudes of users towards a new technologies and their eventual adoption or rejection ( $\mathrm{Lu}$ et al, 2003). Perceived usefulness is described by Davis (1989, p.320) as "the degree to which a person believes that using a particular system would enhance his or her job performance." A system high in perceived usefulness is considered to positively influence adoption of the specific system (Davis, 1989). On the other hand, perceived ease of use is referred to as "the degree to which a person believes that using a particular system would be free of effort" (Davis, 1989, p.320). A system scoring high in ease of use will encourage users to use the system (Davis, 1989).

The TAM model has been used in various recent items of research into smartphones and mobile consumer behaviour (Holmes et al., 2014). For instance, Lu and Su (2009) used the TAM model to explore factors affecting purchase intention in the context of mobile websites. Their research suggested that negative emotions such as anger have a negative impact on purchase intention whereas positive emotion such as enjoyment has a positive effect on purchase intention (Lamarre et al., 2012; Ozuem, Thomas \& Lancaster 2015). Although TAM is a model frequently cited by researchers, many have mixed opinions, regarding its applications as being limited (Lu et al., 2003). Conversely to TRA, the TAM is criticised for lacking vigour and having limited variables (Davis et al., 1992; Venkatesh et al., 2013). Burton-Jones and Hubona (2006) stated that the original TAM can be modified to include external factors such as age, level of education and experience, which, according to their studies, can affect the use of technology. Mathieson (1991) on the other hand considers the TAM theoretical foundation to be poor and argues that there can be many uncertainties between the intention and adoption phase. However, the Technology Acceptance Model (TAM) remains a useful theoretical framework to assess users' acceptance or rejection of a particular technology (Davis, 1989 cited in Kumar and Mukherjee, 2013). Mobile shopping is an activity which involves interaction between the user and the technology, in this research, the smartphone hence the importance of the users' attitudes towards the said technology.

Researches in the past advocated that positive attitudes and purchase intentions are inter-related (Shim et al., 2001; George, 2002; Goldsmiths \& Bridges, 2005). Eagly and Chaiken (1993, p.1) define attitude as "a psychological tendency that is expressed by evaluating a particular entity with some degree of fa- 
vour or disfavour." The many definitions of attitude emphasise the nature of the term and its connection with behaviour (Bohner \& Bohner, 2001). For instance, Seock and Norton (2007) argue that consumers' attitudes towards a specific shopping channel will influence their likelihood to purchase through that channel. Therefore, consumers' perception of the mobile internet to search for information about products and services will eventually influence their intentions to undertake those searches via their smartphones and the likelihood to purchase online (Kim et al., 2012). It has been argued further that attitude towards a technology (i.e. mobile internet) will determine the probability of a consumer using that technology (i.e. smartphones) as a medium to make a purchase. The consumers' intentions (Seock \& Norton, 2007) and their objectives (Nysveen \& Pedersen, 2005) will contribute towards a high-degree goal-oriented search mode which will influence the purchase intentions in an online mobile environment. As pointed out by both George (2002) and Seock and Norton (2007), a positive attitude towards online shopping will culminate in a positive purchase intention whereas a negative attitude towards online shopping will result in negative purchase intentions.

\section{Smartphones and Mobile Shopping}

Considerable evidence from industry sources reveals that mobile phones are playing a significant role in consumers' shopping processes (Skeldon, 2012; Seock \& Norton, 2007). With the prediction of increased adoption of smartphones in future, there will inevitably be continuous growth in this new shopping trend. The use of smartphones for shopping is not restricted to purchasing but is more thoroughly used for activities such as searching for products, gathering production information, checking prices or reading reviews (Holmes et al., 2014). The ability to conduct shopping activities on mobile devices has opened up opportunities for retailers to influence the purchase intentions of shoppers (Shankar et al., 2011).

To understand the term mobile shopping, it is important to understand consumer buying behaviour. Consumer buying behaviour involves the process and activities entailed when consumers are searching, evaluating, analysing, buying, reviewing, rejecting, accepting products or services with a view to satisfying their personal needs. Solomon (2009, p.33) defines consumer behaviour as "the study of the processes involved when individuals or groups select, purchase, use, or dispose of products, services, ideas, or experiences to satisfy their needs and desires." According to Peter and Olson (1996), consumers' buying decisions are divided into interpretation, integration and behaviour. Interpretation deals with how consumers select information and derive meanings from particular information (Peter \& Olson, 1996). Then, the integration happens when the consumer evaluates the product using various sources of information among other alternative behaviours towards the product (Peter \& Olson, 1996). This is an important stage in the decision-making process that will eventually result in either the customer buying or rejecting the product (Peter \& Olson, 1996). Nysveen and Pedersen (2005) identify the consumers' objectives as the ultimate factor that will influence the consumers search for a product and hereafter the buying behaviour. In their opinion, consumers with a high-degree goal-oriented search mode which is influenced by product knowledge, product risk and product involvement are more likely to complete a transaction than consumers with a low-degree search mode (Nysveen \& Pedersen, 2005).

Mobile shopping is the process of consumers exhibiting particular buying behaviours in an online mobile environment (Skeldon, 2012). Easy access to internet on the go via smartphones has fuelled the ability of consumers to be more-goal oriented in their search for products (Nysveen \& Pedersen, 2005). To assist them in their information search and in some cases buying process, smartphones are now the convenient medium. Increased adoption and functionality of smartphones means consumers are making 
ever greater use of their smartphones in the shopping process anywhere and anytime (Charlton, 2011). New technological developments in smartphones have indeed opened up opportunities for retailers to influence shopper attitudes and behaviours (Holmes et al., 2014).

\section{Online Shopping Motivations}

Salomon and Rabolt (2006) describe motivation as the processes that drive people to behave in a particular manner. In the shopping context, motivations will be the behavioural factor that will ultimately drive shopping behaviour (Jim \& Kim, 2003). Babin et al. (1994) identified two primary drivers of shopping motivations as being attributed to utilitarian and hedonic reasons. Adapting a traditional approach, shopping motivations were seen as highly task-related and rational from a utilitarian perspective (Kim, 2006). Babin et al. (1994), however, argued that shopping motivations are identified by the perception of shopping from the consumer point of view whether they see it as an activity of cognition or one of pleasure. Hence, the two perspectives of shopping motivations are identified as utilitarian and hedonic shopping motivations (Babin et al., 1994). The utilitarian aspects of shopping considered shopping as a task to be performed in a timely and efficient manner (Childers et al., 2001). These shoppers will use their mobiles to search for product information and offers online at their convenience to fulfill their motives, which plays an important role in shaping their shopping behaviour (Childers et al., 2001).

Similarly, Babin et al. (1994) argue that shopping motivations need not be restricted to product or task-orientation but can also be hedonic. Consistent with these findings, Hoffman and Novak (1996) state that hedonic shopping motivation is associated with the entertainment and enjoyment derived from the shopping activity. Kim and Forsythe (2007) identify hedonic shoppers as those who seek pleasure and fun in the shopping process. Childers et al. (2001) state that the social activity for hedonic shoppers is not limited to product acquisitions but involves the activity of browsing or seeking excitement in surfing. Hedonic shoppers are considered as more apt to engage in online shopping, as their main motives are for non-economic reasons such as fun, social or emotional gratification (Park et al., 2006). Arnold and Reynolds (2003) conducted research regarding the hedonic aspects of shopping which resulted in a range of motives from adventure, gratification, value, social, role and idea shopping motivations being identified. Although these two aspects are considered to offer contrasting conceptual approaches to shopping, they are both considered important in shaping consumer buying behaviour (Babin et al., 1994). Scarpi (2006) suggests that consumers with a high level of hedonism tend to purchase on a frequent basis compared with consumers with a high level of utilitarianism. Childers et al. (2001) confirmed that both usefulness and enjoyment associated with purchasing a product have a positive effect on consumers' purchase intentions. Accordingly, these findings show that both hedonism and utilitarianism shape consumers' perceptions and adoption of online shopping (Babin et al., 1994; Scarpi, 2006).

\section{Establishing Trust in a Mobile Environment}

Trust is an important element that can promote or deter consumers from using smartphones for shopping processes as emphasised by Yeh and Li (2008). Trust is an important element which can ensure consumers' satisfaction and which can thus lead to consumer retention for both online and offline retailers (Schiffman \& Kanuk, 2010). Satisfaction and trust are closely related in the online shopping experience and to benefit from this consumers place high importance on website design, reliability, responsiveness, trust and personalisation when conducting online purchase (Yeh \& Li, 2008). Satisfaction is a strong 
factor which will determine the level of trust established with consumers and this happens at the postpurchase stage (Yeh \& Li, 2008). There should be a strong similarity in what consumers are expecting to be offered and what is being provided by the online service (Yeh \& $\mathrm{Li}, 2008$ ). Consequently, retailers need to focus on enhancing their mobile commerce with minimum hindrance in their mobile sites so as to encourage consumers to shop through their smartphones more frequently (Skeldon, 2011). Wang and Liao (2007) highlighted the fact that a successful online mobile experience will most likely encourage future online purchase. Other major concerns that influence consumers purchase intentions in a mobile environment are security and data protection (Yeh \& Li, 2009). This is an on-going hindrance affecting purchase intentions on smartphones.

As mentioned earlier, consumers' attitudes towards their smartphones are an important consideration when studying the mobile shopping process. Consumers perceive their smartphones as personal and may consider it an intrusion if they are bombarded with commercials or advertising all the time (Holmes et al., 2014). The element of trust is thus considered crucial as consumers are becoming more conscious about source credibility (Spaid \& Flint, 2014). Consumers do intense research prior to purchase and thus online retailers need to provide genuine information to assist potential consumers (Solomon, 2009) The shopping experience via smartphones needs to be perceived as relevant, useful and timely and possibly funny, to establish a trust relationship (Hung et al., 2012). Another factor that affects the trust element in consumers' willingness to adopt online shopping can be attributed to the quality of service they are being offered online (Chemingui \& Lallouna, 2013). In the absence of a salesperson to guide them in their shopping process, it is crucial for the quality of service online to be perceived as exceptionally good (Chemingui \& Lallouna, 2013). The first online shopping experience contributes towards building an initial trust relationship between the retailers and the shoppers which will lead to future online shopping (Zhou, 2011). In the apparel sector, although customisation of clothes is now possible with body-scanning technology, many consumers are reluctant to use this shopping format (Cho \& Fiorito, 2009). Zhou (2011) further argues that it is even harder to establish a trust relationship in a virtual environment due to great uncertainty and trust. Therefore, it is important for retailers to concentrate on enhancing their mobile commerce strategies to maintain brand credibility and integrity (Chemingui \& Lallouna, 2013). Considering that consumers still favour the PC and physical stores in the clothing sector, it is very interesting by conducting this research to see what affects their purchase intentions via smartphones and what changes they expect in the future. The element of trust is difficult to achieve in a mobile environment as the threats involved are considered very high and very difficult to eradicate.

\section{Smartphones and Purchase Intentions}

The rapid adoption and use of smartphones has driven many cultural changes including changes in consumers' shopping patterns and shopping behaviour (Spaid \& Flint, 2014). Most existing studies have been focused on identifying the main variables responsible for consumers' purchasing behaviour in the mobile online environment (Kumar \& Mukherjee, 2013; Spaid \& Flint, 2014; Holmes et al., 2014; Ting et al., 2011). While some researchers attribute attitudes and consumers' perception as the main determinants that influence the use of smartphones as a shopping tool (Holmes et al., 2014; Lu $\& \mathrm{Su}, 2009$; Lu et al., 2003), others consider motivation as a major factor contributing towards the use of smartphones as a shopping channel (Childers et al., 2001; Kim \& Forsythe, 2007; Park et al., 2006). Whichever the variables that determine the use of smartphones to conduct shopping activities may be, 
it is evident that smartphones and purchase intentions are inter-related (Seock \& Norton, 2007; Skeldon, 2012; Elkin, 2013).

The technology acceptance model (TAM) is indeed a useful tool in assessing users' willingness to adopt smartphones as the new purchase channel (Kumar \& Mukherjee, 2013; Spaid \& Flint, 2014). This model had been used, and in certain research modified with a view to ascertaining a more defined understanding of how this new technology is continuously reshaping the shopping process. The common variables identified by a variety of research in this new field are attitudes, intention and behaviour (Spaid \& Flint, 2014, Lu et al., 2003; Seock \& Norton, 2007; Holmes, 2014). Ting et al..(2011) identified perception of and dependency on the smart device as major attributes that influence user's attitude towards using a smartphone. Due to a shortage of time, consumers find it convenient to use their smartphones anywhere and anytime to perform multiple tasks (Dibb \& Carrigan, 2013). They perceive their smartphones as the ultimate device that performs the task of both a mobile phone and a laptop (Lu \& Su, 2009). Consequently, consumers with a positive perception of the multi-usage capabilities of smartphones are identified as having a positive attitude towards the adoption of smartphones as a multitasking device (Kumar \& Mukherjee, 2013; Ozuem \& Lancaster 2014). Behavioural intention relates to the phase where an individual's attitude gradually controls or guides his or her behaviour (Ajzen, 1991). In the context of mobile shopping, attitude and motivation are considered the determinants of behavioural intention (Kim, 2006; Scarpi, 2006). Whether for utilitarian or hedonic reasons, positive motivation and initial attitude are believed to trigger the use of a smartphone as a shopping tool and henceforth purchase intention (Kim, 2006; Scarpi, 2006). The actual behaviour is the last phase of the technology acceptance model in which the users' decision to use the device culminates (Ajzen, 1991). In the context of this research, actual behaviour happens when consumers do in fact use the device for a shopping experience. Consumers' actual usage of this new shopping technology does not necessarily guarantee ultimate adoption of smartphones as a shopping channel (Yeh \& Li, 2008). The first mobile shopping experience is considered as a crucial touchpoint that will initiate future purchase (Skeldon, 2012), hence, the growing importance of mobile commerce in this new digitalised marketplace (Zhou, 2011). The importance of a good mobile site, easy user interface, enhanced security and an overall sound mobile experience are the major contributors towards effective adoption of this new shopping tool (Yeh $\& \mathrm{Li}, 2009$ ). Considering the clothing sector, the challenge is even bigger as the sensory feelings of products constitute a major determinant of actual purchase (eMarketer, 2013). Moreover, as per research carried out by eMarketer (2013), although mobile commerce has shown considerable growth in the last few years, the personal desktop remains the most favoured device for online purchases.

The theory of reasoned action (TRA) and the theory of planned behaviour (TPB) are both attitudinal theories that will assist in gaining in-depth knowledge about shoppers' attitudes towards mobile technology (Ozuem, Borrelli, \& Lancaster, 2015). The technology acceptance model remains the ultimate tool that will be used in this research to understand the different phase that constitutes the shopping process in a mobile environment. The main gap in the literature lies between the behavioural intention phase and actual behaviour. Though research has focused on different variables that might be integrated in the model to have a clearer picture on how shopping behaviour might be influenced in a mobile environment, little relates to how smartphones can influence purchase intention. Hence, the focus of the research will be to establish a link between smartphones and purchase intention with particular emphasis on those variables that affect the acceptance of this new shopping technology. 


\section{CONCLUSION AND MANAGERIAL IMPLICATIONS}

Understanding the motivational factors and features that contribute to an effective and efficient mobile retail channel is of primary significance for retailers, including the clothing sector, with a view to selling their products successfully online and offline. For instance, consumers' pre-purchase activities using their smartphone are mainly directed towards deals and lower prices, both of which are driven by goaloriented motivation. Therefore, marketers should revise their mobile commerce strategies to cater for and attract price-sensitive consumers. The challenge is to be the price leader with active promotional offers, deals and online discounts to attract consumers to their websites and to deter them from moving to competitors' websites.

Motivation is considered strategic to entertain consumers in a mobile retail setting. Whether the initial motive for shopping is task-related or for enjoyment, the objective of retailers is to ensure consumers' satisfaction at all stages of the shopping process. Therefore, marketers should develop marketing strategies aimed at encouraging consumers to conduct shopping activities online. Such strategies might include promotional offers, click-to-buy options, click-to-collect options, free delivery service, next day delivery service or online coupons which are commonly favoured by online shoppers.

Although many consumers conduct direct purchase on their smartphones, the majority use their devices for pre-purchase activities. These activities mostly include information enquiries regarding product specifications, product price, reviews and availability. In today's knowledge-based society, consumers are more willing to explore their personalised needs by using their smartphones prior to engaging in any form of transaction. Communications in the retail environment has evolved by involving consumers in the interactive platform of mobile commerce, targeted at providing information that meets consumers' expectation. Hence, marketers need to focus on the allocation of accurate and updated databases on their mobile sites to assist mobile shoppers with information queries at all times.

Trust is an important element that contributes to the establishment of a good rapport between consumers and retailers. This has emerged as a key variable within this study and constitutes a strategic element to encourage adoption of smartphones both for pre-purchase activities and for immediate purchase. Online retailers should thus ensure that consumers enjoy the mobile retail channel by implementing enhanced mobile commerce. This involves investment of resources towards a mobile site with user-friendly interface, easy access to commonly researched information and safe click-to-buy or click-to-collect in-store options. Furthermore, considering consumers' trustworthiness in social interaction for an authentic information, a mobile site needs to integrate features of social media to enhance consumers' experience and improve transparency in the mobile retail environment. Overall, consumers need to perceive mobile shopping as a convenient, safe shopping medium.

Intense innovation in features of smartphones and wireless technologies has freed users from the tethers that initially bounded them to their desks for online shopping. Convenience and flexibility are key features that initiate the use of smartphones for shopping irrespective of time and location. This is a golden opportunity for retailers to establish a mobile presence by making efficient use of mobile technology. Smartphones are now equipped with wide and high resolution screens which emphasise the need for marketers to implement a mobile site interface that closely matches the laptop or PC experience. Mobile sites need to improve navigation that will assist consumers whilst browsing for information they value at their convenience thus enriching their shopping experience. Marketers need to ensure that their mobile site is compatible and up-to-date with latest technologies such as fingerprint recognition, digital wallets, heartbeat rate, retinal recognition and other emerging technologies to attract and retain 
more consumers in the mobile environment. In successfully implementing such strategies, consumers will find it even more convenient to adopt mobile shopping and will also entertain a trusting relationship with the mobile retail channel.

By understanding the link between smartphone and purchase intention, marketers can adapt their marketing strategies to positively influence more users to conduct at least pre-purchase activities in a mobile environment. They need to acknowledge and analyse further variables valued by mobile consumers, and evaluate ways to improve these variables with a view of gaining and retaining mobile shoppers. Although the findings in this study are not exhaustive, they provide a snapshot into understanding the relationship between the smartphone and mobile shoppers' behavioural intention.

\section{REFERENCES}

Abrams, K. V. (2012). UK B2C Ecommerce: Mobile Takes Center Stage. Emarketer. Retrieved from http://www.emarketer.com/Article/Mobile-Gains-Speed-UK-Ecommerce-

Abrams, K. V. (2013). UK Digital Trends: Ecommerce, Video and Mobile Thrive, but Brands must work for loyalty and trust. Emarketer.

Abrams, K. V. (2013). Western Europe B2C Ecommerce: Solid Growth Continues as Mobile Gains Ground. Emarketer.

Ahrens, J., Coyle, J. R., \& Strahilevitz, M. A. (2013). Electronic word of mouth: The effects of incentives on e-referrals by senders and receivers. International Journal of Marketing, 47(7), 1034-1051.

Arnold, M. J., \& Reynolds, K. E. (2003). Hedonic shopping motivations. Journal of Retailing, 79(2), 77-95. doi:10.1016/S0022-4359(03)00007-1

Banerjee, S., \& Dholakia, R. R. (2012). Location-based mobile advertisements and gender targeting. Journal of Research in Interactive Marketing, 6(3), 198-214. doi:10.1108/17505931211274679

Barrutia, J. M., \& Echebarria, C. (2013). Networks: A social marketing tool. European Journal of Marketing, 47(1/2), 324-343. doi:10.1108/03090561311285574

BBC. (2012). UK's first $4 G$ mobile service launched in 11 cities by EE. Retrieved from http://www.bbc. co.uk/news/technology-20121025

BBC. (2013). The peril of "showrooming”. Retrieved from http://www.bbc.co.uk/news/magazine-22098575

Bohner, M., \& Bohner, G. (2001). Intrapersonal processes. Oxford: Blackwell.

Boyatzis, R. E. (1998). Transforming qualitative information: Thematic analysis and code development. California: Sage Publications Inc.

Boyle, C. (2013). Retail Mobile Commerce Forecast: Shoppers Turn to Smartphones First. Emarketer. Retrieved from http://www.emarketer.com/Article/More-Shoppers-Reach-Mobile-Browse-Buy/1009615

Braun, V., \& Clarke, V. (2006). Using thematic analysis in psychology. Qualitative Research in Psychology, 3(2), 77-101. doi:10.1191/1478088706qp063oa 
Brown, M., Pope, N., \& Vogues, K. (2003). Buying or browsing?: An exploration of shopping orientations and online purchase intention. European Journal of Marketing, 37(11/12), 1666-1684. doi:10.1108/03090560310495401

Bryman, A. (1988). Contemporary Social Research Series. London: Unwin Hyman Ltd.

Bryman, A. (1989). Research Methods and Organization Studies. London: Unwin Hyman Ltd. doi: $10.4324 / 9780203359648$

Burr, V. (2003). Social Contructionism (2nd ed.). London: Routledge.

Burton-Jones, A., \& Hubona, G. S. (2006). The mediation of external variables in the technology acceptance model. Information \& Management, 43(6), 706-717. doi:10.1016/j.im.2006.03.007

Butler, P., \& Peppard, J. (1998). Consumer Purchasing on the Internet: Processes and Prospects. European Journal of Marketing, 16(5), 600-610.

Chan, F. T. S., \& Yee-Loong Chong, A. (2013). Analysis of the determinants of consumers' m-commerce usage activities. Online Information Review, 37(3), 443-461. doi:10.1108/OIR-01-2012-0012

Cheema, A., \& Papatla, P. (2010). Relative importance of online versus offline information for Internet purchase: Product category and Internet experience effects. Journal of Business Research, 63(9-10), 979-985. doi:10.1016/j.jbusres.2009.01.021

Chemingui, H., \& Ben lallouna, H. B. (2013). Resistance, motivation, trust and intention to use mobile finance services. International Journal of Bank Marketing, 31(7), 574-592. doi:10.1108/IJBM-122012-0124

Cheung, C. M. K., \& Lee, M. K. O. (2012). What drives consumers to spread electronic word of mouth in online consumer-opinion platforms. Decision Support Systems, 53(1), 218-225. doi:10.1016/j. dss.2012.01.015

Childers, T. L., Carr, C. L., Peck, J., \& Carson, S. (2001). Hedonic and utilitarian motivations for online retail shopping behaviour. Journal of Retailing, 77(4), 511-535. doi:10.1016/S0022-4359(01)00056-2

Cho, S., \& Fiorito, S. S. (2009). Acceptance of online customization for apparel shopping. International Journal of Retail \& Distribution Management, 37(5), 389-407. doi:10.1108/09590550910954892

Clarke, I. (2008). Emerging Value Propositions for M-commerce. The Journal of Business Strategy, 25(2), 41-57.

Clothing Retailing Market Report. (2013). Keynote. Retrieved from http://www.keynote.co.uk/marketintelligence/view/product/10792/clothing-retailing?highlight=clothing\&utm_source=kn.reports.search

Collis, J., \& Hussey, R. (2003). Business Research: A practical guide for undergraduate and postgraduate students (2nd ed.). New York: Palgrave Macmillan.

Collis, J., \& Hussey, R. (2009). Business Research: A Practical Guide for Undergraduate \& Postgraduate Students (3rd ed.). Hampshire: Palgrave Macmillan. 
Constantinides, E., Lorenzo-Romero, G. M., \& Gómez, M. A. (2010). Effects of web experience on consumer choice: A multicultural approach. Internet Research, 20(2), 188-209. doi:10.1108/10662241011032245 Creswell, J. W. (1994). Research design: Qualitative and Quantitative Approaches. Thousand Oaks: Sage.

Davis, F. D., Bagozzi, R. P., \& Warshaw, P. R. (1989). User acceptance of computer technology: A comparison of two theoretical models. Management Science, 35(8), 982-1003. doi:10.1287/mnsc.35.8.982

Demangeot, C., \& Broderick, A. J. (2007). Conceptualising consumer behaviour in online shopping environments. International Journal of Retail \& Distribution Management, 35(11), 878-894. doi:10.1108/09590550710828218

Denzin, N. K. (1970). The Research Act: A theoretical Introduction to Sociological Methods. New York: McGraw-Hill.

Denzin, N. K., \& Lincoln, Y. S. (2000). The Handbook of Qualitative Research (2nd ed.). Thousand Oaks: Sage.

Dholakia, R. (1999). Going shopping: Key determinants of shopping behaviors and motivations. International Journal of Retail \& Distribution Management, 27(4), 140-165.

Dholakia, R. R., \& Dholakia, N. (2004). Mobility and markets: Emerging outlines of m-commerce. Journal of Business Research, 57(12), 1391-1396. doi:10.1016/S0148-2963(02)00427-7

Dibb, S., \& Carrigan, M. (2013). Social marketing transformed. European Journal of Marketing, 47(9), 1376-1398. doi:10.1108/EJM-05-2013-0248

Dittmar, H., \& Drury, J. (2000). Self-image - is it in the bag? A qualitative comparison between 'ordinary' and 'excessive' consumers. Journal of Economic Psychology, 21(2), 109-142. doi:10.1016/ S0167-4870(99)00039-2

Eagly, A. H., \& Chaiken, S. (1993). The psychology of Attitudes. Fort Worth, TX: HarcourtBrace Jovanovich.

Frolick, M. N., \& Chen, L. (2004). Assessing M-Commerce Opportunities. Information Systems Management, 21(2), 53-61. doi:10.1201/1078/44118.21.2.20040301/80422.8

Gamble, J., \& Gilmore, A. (2013). A new era of consumer marketing? An application of co-creational marketing in the music industry. European Journal of Marketing, 47(11/12), 1859-1888. doi:10.1108/ EJM-10-2011-0584

George, J. F. (2002). Influence on the intent to make internet purchase. Internet Research: Electronic networking Applications and Policy, 12(2), 165-180.

Goldsmiths, R. E., \& Bridges, E. (2000). E-tailing vs retailing: Using attitude to predict online buying behaviour. Quarterly Journal of Electronic Commerce, 1(3), 245-253.

Gomm, R. (2004). Social research methodology: a critical introduction. Basingtoke: Palgrave Macmillan. Guest, G., MacQueen, K. M., \& Namey, E. E. (2012). Applied Thematic Analysis. Los Angeles: Sage publications Inc. doi:10.4135/9781483384436 
Hartas, D. (2010). Educational Research and Inquiry: Qualitative and Quantitative Approach. London: Continuum International Publishing Group.

Hill, W. W., Beatty, S. E., \& Walsh, G. (2013). A segmentation of adolescent users and shoppers. Journal of Services Marketing, 27(5), 347-360. doi:10.1108/JSM-10-2011-0157

Hoffman, D. L., \& Novak, T. P. (1996). Marketing in hype media computer-mediated environments: Conceptual foundations. Journal of Marketing, 60(3), 50-68. doi:10.2307/1251841

Holmes, A., Byrne, A., \& Rowley, J. (2014). Mobile shopping behaviour: Insights into attitudes, shopping process involvement and location. International Journal of Retail \& Distribution Management, 42(1), 25-39. doi:10.1108/IJRDM-10-2012-0096

Hsu, C. L., Lin, J. C. C., \& Chiang, S. H. (2013). The effects of blogger recommendations on customers' online shopping intentions. Internet Research, 33(1), 69-88. doi:10.1108/10662241311295782

Hu, W.-C., Yeh, J.-H., Fu, L., \& Yang, H.-J. (2006). Handheld Computing and Programming for Mobile Commerce. International Journal of Web Information Systems, 2(3/4), 164-175. doi:10.1108/17440080780000297

Hung, M. C., Yang, S. T., \& Hsieh, T. C. (2012). An examination of the determinants of mobile shopping continuance. International Journal of Electronic Business Management, 10(1), 29-37.

In-store Mobile Offers Still Finding Their Feet in the UK. (2013). Emarketer.com. Retrieved from http:// www.emarketer.com/Article/Retail-Drives-UK-B2C-Ecommerce-Sales-Higher/1010106

Kelle, U. (2006). Combining qualitative and quantitative methods in research practice: Purpose and advantages. Qualitative Research in Psychology, 3(4), 203-311.

Khalifa, M., \& Shen, K. N. (2008). Explaining the adoption of transactional B2C mobile commerce. Journal of Enterprise Information Management, 21(2), 110-124.

Kim, H., Kim, J. L. Y., Chae, M., \& Choi, Y. (2002). An empirical study of the use context and usability problems in mobile internet. Hawaii: IEEE Computer Society.

Kim, H.-W., Xu, Y., \& Gupta, S. (2012). Which is more important in Internet Shopping, perceived price or trust? Electronic Commerce Research and Applications, 11(3), 241-252.doi:10.1016/j.elerap.2011.06.003

Kourouthanassis, P. E., \& Giaglis, G. M. (2012). Introduction to the Special Issue Mobile Commerce: The Past, Present and Future of Mobile Commerce Research. International Journal of Electronic Commerce, 16(4), 5-17. doi:10.2753/JEC1086-4415160401

Kumar, A., \& Mukherjee, A. (2013). Shop while you talk: Determinants of purchase intentions through a mobile device. Mobile Marketing Association, 8(1), 23-37.

Kumar, S., \& Zhan, C. (2003). Mobile communications: Evolution and the impact on business operations. Technovation, 23(6), 515-520. doi:10.1016/S0166-4972(02)00120-7

Lamarre, A., Galarneau, S., \& Boeck, H. (2012). Mobile Marketing and consumer Behaviour Current Research Trend. International Journal of Latest Trends in Computing, 3(1), 1-9. 
Li, M., Dong, Z. Y., \& Chen, X. (2012). Factors influencing consumptions experience of mobile commerce. Internet Research, 22(2), 120-141. doi:10.1108/10662241211214539

Lu, J., Yu, C.-S., Liu, C., \& Yao, J. E. (2003). Technology acceptance model for wireless internet. Internet Research: Electronic Networking Applications and Policy, 13(3), 206-222. doi:10.1108/10662240310478222

Markovic, M. (2006). Analysing Qualitative Data: Health care experiences of Women with Gynecological Cancer. Field Methods, 18(4), 413-429. doi:10.1177/1525822X06293126

Marks, D., \& Yardley, L. (2004). Research methods for clinical and health psychology. London: Sage.

Mathieson, K. (1991). Predicting user intentions: Comparing the technology acceptance model with the theory of planned behaviour. Information Systems Research, 2(3), 173-191. doi:10.1287/isre.2.3.173

Miles, C. (2013). Persuasion, marketing, communication, and the metaphor of magic. European Journal of Marketing, 47(11/12), 2002-2019. doi:10.1108/EJM-11-2011-0632

Mobile Cocooning: How Growing Reliance on Smart Devices is Influencing Consumer Behaviour. (2013). Emarketer.com. Retrieved from http://www.euromonitor.com/mobile-cocooning-how-growingreliance-on-smart-devices-is-influencing-consumer-behaviour/report

Mobile's Share of UK Digital Retail Sales Doubles. (2013). Emarketer.com. Retrieved from http://www. emarketer.com/Article/Mobiles-Share-of-UK-Digital-Retail-Sales-Doubles/1010204

Moth, D. (2013). Mobile commerce now accounts for 23\% of online sales: report. Econsultancy.com. Retrieved from https://econsultancy.com/blog/63338-mobile-commerce-now-accounts-for-23-of-onlinesales-report

Nysveen, H., \& Pedersen, P. E. (2005). Search mode and purchase intention in online shopping behaviour. International Journal of Internet Marketing and Advertising, 2(4), 288-306. doi:10.1504/ IJIMA.2005.008103

Online retail sales highest in two years as positive economic sign continues. (2013). Capgemini. Retrieved from http://www.uk.capgemini.com/online-retail-sales-highest-in-two-years-as-positive-economic-signscontinue

Ozuem, W., Borrelli, M., \& Lancaster, G. (2015). Leveraging the co-evolution of offline and online video games: An empirical study. Journal of Strategic Marketing, 1-23. doi:10.1080/0965254X.2015.1076883

Ozuem, W., Howell, K. E., \& Lancaster, G. (2008). Communicating in the new interactive marketspace. European Journal of Marketing, 42(9/10), 1059-1083. doi:10.1108/03090560810891145

Ozuem, W., \& Lancaster, G. (2014). Recovery strategies in on-line service failure. In A. Ghorbani (Ed.), Marketing in the cyber era: strategies and emerging trends (pp. 143-159). Hershey, PA: IGI Global.

Ozuem, W., O’Keeffe, A., \& Lancaster, G. (2015). Leadership Marketing: An exploratory study. Journal of Strategic Marketing, 1-25. doi:10.1080/0965254X.2014.1001867

Ozuem, W., Thomas, T., \& Lancaster, G. (2015). The Influence of customer loyalty on small island economies: An empirical and exploratory study. Journal of Strategic Marketing, 1-23. doi:10.1080/09 65254X.2015.1011205 
Parasuraman, A. (2000). Technology readiness index (TRI) a mutiple-item scale to measure readiness to embrace new technology. Journal of Service Research, 2(4), 307-320. doi:10.1177/109467050024001

Park, E. J., Kim, E. Y., \& Forney, J. C. (2006). A structural model of fashion-oriented impulse buying behaviour. Journal of Fashion Marketing and Management, 10(4), 433-446. doi:10.1108/13612020610701965

Pasqua, R., \& Elkin, N. (2013). Mobile Marketing: An hour a day. Indiana: John Wiley \& Sons Inc.

Patton, M. Q. (2002). Qualitative Research and Evaluation Methods (3rd ed.). London: Sage Publications Ltd.

Persaud, A., \& Azhar, I. (2012). Innovative mobile marketing via smartphones: Are consumers ready? Marketing Intelligence \& Planning, 30(4), 418-443. doi:10.1108/02634501211231883

Peter, J. P., \& Olson, J. (1996). Consumer behaviour and marketing strategy. Chicago: Irwin.

Qu, Z., Wang, Y., Wang, S., \& Zhang, Y. (2013). Implications of online social activities for e-tailer's business performance. European Journal of Marketing, 47(8), 1190-1212. doi:10.1108/03090561311324282

Retail Drives UK B2C Ecommerce Sales Higher. (2013). Emarketer.com. Retrieved from http://www. emarketer.com/Article/Retail-Drives-UK-B2C-Ecommerce-Sales-Higher/1010106

Robson, C. (2011). Real World Research: A Resource for Users of Social Research Methods in Applied settings (3rd ed.). Cornwall: John Wiley \& Sons Ltd.

Rogers, E. M. (1995). Diffusion of Innovations. New York: The Free Press.

San-Martin, S., \& Lopez-Catalan, B. (2013). How can a mobile vendor get satisfied customers? Industrial Management \& Data Systems, 113(2), 156-170. doi:10.1108/02635571311303514

San-Martin, S., Lopez-Catalan, B., \& Ramon-Jeronimo, M. A. (2012). Factors determining firms' perceived performance of mobile commerce. Industrial Management \& Data Systems, 112(6), 946-963. doi:10.1108/02635571211238536

Saunders, M., Lewis, P., \& Thornhill, A. (2009). Research methods for business students (5th ed.). Harlow: Pearson Education Ltd.

Scarpi, D. (2006). Fashion stores between fun and usefulness. Journal of Fashion Marketing and Management, 10(1), 7-24. doi:10.1108/13612020610651097

Schiffman, L. G., \& Kanuk, L. L. (2010). Consumer Behaviour (10th ed.). New Jersey: Pearson Education Inc.

Schuster, L., Drennan, J., \& Lings, I. N. (2013). Consumer acceptance of m-wellbeing services: A social marketing perspective. European Journal of Marketing,47(9), 1439-1457. doi:10.1108/EJM-10-2011-0556

Seock, Y. K., \& Norton, M. (2007). Attitude towards internet websites, online information search and channel choices for purchasing. Journal of Fashion Marketing and Management, 11(4), 571-586. doi:10.1108/13612020710824616

Shim, S., Estlick, M. A., Lotz, S. L., \& Warrrington, P. (2001). An online prepurchase intentions model: The role of intention to search. Journal of Retailing, 77(2), 307-416. 
Skeldon, P. (2011). M-commerce: Boost your business with the power of mobile commerce. Richmond: Crimson Publishing.

Solomon, M. R. (2009). Consumer Behaviour: Buying, Having and Being (8th ed.). New Jersey: Pearson Education Inc.

Spaid, B. I., \& Flint, D. J. (2014). The meaning of shopping experiences augmented by mobile internet devices. Journal of Marketing Theory and Practice, 22(1), 73-89.

Swilley, E., \& Hofacker, C. F. (2006). Defining mobile commerce in a marketing context. International Journal of Mobile Marketing, 1(2), 18-23.

Swilley, E., Hofacker, C. F., \& Lamont, B. T. (2012). The Evolution of E-Commerce to M-Commerce: Pressures, Firm Capabilities and Competitive Advantage in Strategic Decision Making. International journal of e-business research, 8(1), 1-16.

Three of Four UK Mobile Users Own Smartphones by 2016. (2013). Emarketer.com. Retrieved from http:// www.emarketer.com/Article/Three-of-Four-UK-Mobile-Users-Own-Smartphones-by-2016/1009614

Ting, D. H., Ling, S. F., Patanmacia, T. S., Low, C. G., \& Ker, G. C. (2011). Dependency on smartphone and the impact on purchase behavior. Young Consumers, 12(3), 193-203.

UK Online Clothing Shoppers Still Favor the PC. (2013). Emarketer.com. Retrieved from http://www. emarketer.com/Article/UK-Online-Clothing-Shoppers-Still-Favor-PC/1010274

Van Slyke, C., Belanger, F., \& Comunale, C. L. (2004). Factors influencing the adoption of web-based shopping: The impact of trust. ACM SIGMIS Database, 35(2), 32-49.

Venkatesh, V., Brown, S., \& Bala, H. (2013). Bridging the Qualitative- Quantitative Divide: Guidelines for Conducting Mixed-Methodology Research in Information Systems. Management Information Systems Quarterly, 37(1), 21-54.

Wang, M.-S., Chen, C. C., Chan, S.-C., \& Yang, Y.-H. (2007). Effects of online shopping attitudes, subjective norms and control beliefs on online shopping intentions: A test of the theory of planned behaviour. International Journal of Management, 24(2), 296-302.

Wang, Y., \& Liao, Y. (2007). The conceptualization and measurement of m-commerce user satisfaction. Computers in Human Behavior, 23(1), 381-398.

Wheeler, E. (2013). The emergence of M-Commerce and Geofencing. Bloomberg.com. Retrieved from http://www.bloomberg.com/video/from-e-commerce-to-m-commerce-bW0SIsCkRJaTiNTJ89zAnQ.html

Wong, S. H. R. (2012). Which platform do our users prefer: Website or mobile app? RSR. Reference Services Review, 40(1), 113-115.

Yang, K., \& Kim, H.-Y. (2012). Mobile shopping motivation: An application of multiple discriminant analysis. International Journal of Retail \& Distribution Management, 40(10), 778-789.

Yang, S. C. (2012). Mobile applications and 4G wireless networks: A framework for analysis. CampusWide Information Systems, 29(5), 344-357. 
Yeh, Y. S., \& Li, Y.-M. (2009). Building trust in e-commerce: Contributions from quality and satisfaction. Online Information Review, 33(6), 1066-1086.

Zhou, T. (2011). Examining the critical success factors of mobile site adoption. Online Information Review, 35(4), 636-652.

Zhou, T. (2013). Understanding continuance usage of mobile site. Industrial Management \& Data Systems, 113(9), 1286-1299.

\section{KEY TERMS AND DEFINITIONS}

Mobile Commerce: Mobile commerce encompasses the buying and selling of goods and services online through wireless handheld devices usually smartphones or tablets.

Mobile Environment: The mobile environment is the move of the online environment towards the mobile platform to enable smartphones users to access and interact with online contents on the go.

Mobile Shopping: Mobile shopping refers to the action of using a smartphone to browse, compare or to shop for products and services online.

Mobile Storefront: Mobile storefront is when a business establishes an online presence by displaying their products and services on a mobile platform usually via a mobile website. It replaces the conventional storefront whereby consumers can browse for products' information and make purchases through their smartphones without having to physically go to a store.

Online Consumption: Online consumption refers to the action of using up resources, products and services in online environments or technology-enabled marketing platforms.

Showrooming: Showrooming is the action of using a smartphone to browse and compare goods and services online while being in a conventional store before considering a purchase.

Smartphones: A smartphone is an intelligent multi-functional handset capable of the traditional function of a mobile phone device (i.e making phone calls), along with highly advanced features such as internet access, high resolution cameras, GPS system and an operating system capable of running downloaded apps. 